\title{
THE INVESTIGATION OF THREE POTENTIAL ENERGY CROPS: COMMON MUGWORT, CUP PLANT AND VIRGINIA MALLOW ON WESTERN LITHUANIA'S ALBELUVISOL
}

\author{
ŠIAUDINIS, G. ${ }^{*}$ - SKUODIENĖ, R. - REPŠIENĖ, R. \\ Vëzaičiai Branch of the Lithuanian Research Centre for Agriculture and Forestry - LAMMC, \\ Lithuania, Klaipéda dist., Gargždu g. 29, 96216, Vëžaičiai \\ *Corresponding author \\ email: gintaras.siaudinis@vezaiciai.lzi.lt; phone: +370-46-45-82-33 \\ (Received 30 $0^{\text {th }}$ Aug 2016; accepted $7^{\text {th }}$ Mar 2017)
}

\begin{abstract}
Research on novel energy crops - common mugwort (Artemisia vulgaris L.), cup plant (Silphium perfoliatum L.) and Virginia mallow (Sida hermaphrodita Rusby) was set up on a naturally acid Albeluvisol in West Lithuania. The study was aimed to evaluate the effect of year (growing conditions), liming and nitrogen fertilization on biomass yield, its structure as well as lime and nitrogen use efficiency. In many cases, year (or growing conditions) and $\mathrm{N}$ fertilization were two determinant factors for all studied parameters (number of stems per plant, stem height, fresh (FM) and dry mass (DM) yield). Liming material had the biggest impact on the number of stems, stem height and biomass yield of Virginia mallow and less obvious for other two species. Among three crops, the highest productivity was recorded for cup plant in the $3^{\text {rd }}$ harvest year - the average FM yield was $45.20 \mathrm{t} \mathrm{ha}^{-1}$ and that of DM $13.45 \mathrm{t} \mathrm{ha}^{-1}$. The highest lime use efficiency (LUE) values for all three crops obtained in the $2^{\text {nd }}$ year of growing. The highest nitrogen use efficiency (NUE) was obtained in the $1^{\text {st }}$ (for common mugwort 30.71 ) and $2^{\text {nd }}$ year of growing (for cup plant and Virginia mallow - 59.69 and 46.17, respectively).
\end{abstract}

Keywords: energy crops, lime, nitrogen, yield parameters, NUE, LUE

\section{Introduction}

Different kinds of woody and herbaceous plants are being widely investigated for bioenergy purposes in many European countries. The main characteristics of energy crops are high biomass (dry matter) yield and energy value, which is achievable with relatively small economic and energy inputs. A positive result is highly dependent on the adjustment of individual plant species to growing in certain areas of climate and soil conditions (McKendry, 2002).

The article presents the results of the study on three new but botanically very different perennial energy crops: common mugwort (Artemisia vulgaris L.), cup plant (Silphium perfoliatum L.) and Virginia mallow (Sida hermaphrodita Rusby).

Artemisia genus species are widespread in many countries around the world (Barney and DiTommaso, 2003). Out of them, common mugwort is being studied as a possible source for food and pharmaceutical industry in Lithuania and other countries (Judžentienè and Buzelyte், 2006). In traditional agriculture, mugwort is considered as a weed with the ability to propagate easily from small rhizome fragments (Barney and DiTommaso, 2003). It has been reported that Artemisia genus energy value can reach up to $4500 \mathrm{kcal} \mathrm{kg}^{-1}$ (Van Epps et al., 1982). However, there is very little information which is linked to Artemisia species cultivation and their biomass application for biofuel purposes (Kryževičienè et al., 2010).

A cup plant species is originally native to North Eastern US (Huxley, 1992; Clevinger and Panero, 2000). So far, the cup plant physiological and agronomical traits 
have been investigated in different countries (Wrobel et al., 2013; Franzaring et al., 2014). However, there are still many questions to be addressed with regard to its cultivation technology (Voigt et al., 2012; Gansberger et al., 2015).

Similarly, Virginia mallow originates from Northern America (Kujawski et al., 1997). However, many experiments were performed by European researches. Although biomass productivity varies depending on agroclimatic and growing conditions, the productivity of above-ground biomass is comparable with that of other high yielding energy crops - cup plant, basket willow or miscanthus (Borkowska and Molas, 2012; 2013). However, Virginia mallow is still a novel and little-known species in Lithuania and needs a further scientific investigation.

It is important to note that in order to avoid competition with traditional agricultural crops, it is advisable to cultivate energy crops in less fertile soils. For example, naturally acid Albeluvisols and Fluvisols are prevailing in Western Lithuania region. Without maintenance liming, soils return to their original state which leads to the deterioration of their physical, chemical and microbial properties (Mažvila et al., 2004). With increasing demand for biomass for bioenergy industry, a significant proportion of such soils could be used for the cultivation of energy crops. There are few data concerning energy crops productivity under different soil $\mathrm{pH}$ levels.

The current research was aimed to investigate the influence of the different liming (or soil $\mathrm{pH}$ ) and $\mathrm{N}$ rates on the yield, yield structure, nitrogen use efficiency and liming use efficiency of common mugwort, cup plant and Virginia mallow in Albeluvisol.

\section{Materials and methods}

The experiments were performed at Vèžaičiai Branch of the Lithuanian Research Centre for Agriculture and Forestry $\left(55^{\circ} 43^{\prime} \mathrm{N}, 21^{\circ} 27^{\prime} \mathrm{E}\right)$ on a naturally acid moraine loamy soil (Eutri-Hypostagnic Albeluvisol, $\mathrm{ABj}-\mathrm{w}-\mathrm{eu}$ ). Before setting up the trials, the soil of the experimental site was under bare fallow. Agrochemical characteristics of the upper soil layer were as follows: $\mathrm{pH}_{\mathrm{KCl}}-4.25-4.85$, mobile $\mathrm{P}_{2} \mathrm{O}_{5}$ (Egner-RiehmDomingo (A-L)) - 35 - $120 \mathrm{mg} \mathrm{kg}^{-1}$, mobile $\mathrm{K}_{2} \mathrm{O}$ (A-L) - 140-209 mg kg${ }^{-1}$, hydrolytic soil acidity - 21.9-62.1 mequiv kg-1, mobile $\mathrm{Al}-10.7-50.9 \mathrm{mg} \mathrm{kg}^{-1}$.

The subjects of the study were cup plant (Silphium perfoliatum L.), common mugwort (Artemisia vulgaris L.) and Virginia mallow (Sida herhaphrodita Rusby).

The experiments involved two factors. Factor 1 - liming: a) not limed; b) limed by 0.5 rate $\left(3.0 \mathrm{t} \mathrm{ha}^{-1} \mathrm{CaCO}_{3}\right.$ ) (to neutralize the effect of toxic aluminium); c) limed by 1.0 rate $\left(6.0 \mathrm{t} \mathrm{ha}^{-1} \mathrm{CaCO}_{3}\right)$. Factor 2 - nitrogen rates $\left(0,60\right.$ and $\left.120 \mathrm{~kg} \mathrm{ha}^{-1} \mathrm{~N}\right)$. Nitrogen treatments were arranged in a randomized block design with three replications in each $\mathrm{pH}$ (different liming) background.

The experimental site was limed (except for the control treatment) by OPOKOS lime material on April 20 in 2008, just before planting of seedlings. In both years (2009 and 2010), nitrogen fertilizers $\left(60 \mathrm{~kg} \mathrm{ha}^{-1}\right)$ were broadcast at the beginning of April. Treatment 3 was additionally fertilized with $60 \mathrm{~kg} \mathrm{ha}^{-1} \mathrm{~N}$ at the beginning of July. Ammonium nitrate was applied as nitrogen fertilizer. Phosphorus was applied as single superphosphate and potassium - as potassium chloride. Both fertilizers were spread each year before the beginning of vegetation. Potassium and phosphorus rates for all treatments of common mugwort and cup plant were the same $-60 \mathrm{~kg} \mathrm{ha}^{-1} \mathrm{P}_{2} \mathrm{O}_{5}$ and 60 $\mathrm{kg} \mathrm{ha}^{-1} \mathrm{~K}_{2} \mathrm{O}$. 
Common mugwort seedlings were planted on May 27 in 2008. Naturally grown common mugwort plants were used as a planting material for the experiment. Each common mugwort treatment consisted of three 10-meter long rows. The distance between rows was $0.75 \mathrm{~m}^{2}$, and between seedlings in rows $-0.50 \mathrm{~m}^{2}$. The density of mugwort plants was 30.000 plants per ha.

Cup plant seedlings were planted at 2-3 leaf stage on June 3 in 2008 in $10 \mathrm{~m}$ long rows, by keeping $1 \mathrm{~m}^{2}$ distance between each row and $0.5 \mathrm{~m}$ between the seedlings in each row. Each row presents a separate treatment. Thus, the cup plant density was 20000 plants per ha. During planting year, cup plant grows a leaf rosette only; meanwhile shoots start growing from the second year. Both, cup plant and common mugwort investigations for biometrical parameters were started in the growing season 2009.

Virginia mallow seedlings were planted at 3-4 leaf stage on July 10 in 2009. Field parameters were the same as for cup plant. The assessments started from the 2010 growing season.

Nitrogen use efficiency was calculated by the following equation: (DM yield with $\mathrm{N}$ fertilization) - (DM yield without nitrogen fertilization (control))/ $\mathrm{N}$ rate, where $\mathrm{N}$ equals the amount of $\mathrm{N}$ from fertilizer added in $\mathrm{kg} \mathrm{ha}^{-1}$ (Gan et al. 2008). Similarly, lime utilization efficiency (LUE) was calculated in the similar way (DM yield with lime application) - (DM yield liming (control) $) / \mathrm{L}$ rate $\left(\mathrm{t} \mathrm{ha}^{-1} \mathrm{CaCO}_{3}\right.$ rate) rate.

Each year, biomass of all three crops was harvested at the end of vegetation in the $3^{\text {rd }}$ ten-day period of September, using a rotary cutter (Claas, Germany). The fresh (FM) mass yield (or above-ground biomass) was weighed and recalculated into the air-dry mass (DM).

The data of evaluated parameters were statistically processed using analysis of variance (Anova) as a three factorial randomized block variant to determine significant differences between means ( $* \mathrm{P}<0.05$ and $* * \mathrm{P}<0.01$ ), $L S D_{05}$ and $L S D_{01}$ (at $95 \%$ and $99 \%$ probability levels).

In 2009, in the first half of the vegetation season, conditions for plants growing were relatively cool and dry. From the beginning of July until the end of vegetation, the temperature and amount of precipitation were close to annual average. For 2009 growing period, the amount of precipitation was $437 \mathrm{~mm}$. In general, for 2010, the warm and dry period alternated with humid and cool weather until the end of vegetation. The amount of precipitation was $620 \mathrm{~mm}$. In 2011, the weather conditions and rainfall distribution were similar $(540 \mathrm{~mm}$ per vegetation) throughout the whole vegetation. The moderately warm and dry weather was dominating at the beginning of 2012 growing season. The amount of precipitation gradually increased in the second half of vegetation and totalled $394 \mathrm{~mm}$.

\section{Results and discussion}

The results of three factorial analysis (tear, liming rate, nitrogen rate and their interactions) are presented in Table 1. According to Fisher's criterion, year and nitrogen rate were determinant factors affecting the studied parameters for all three crops (at $\mathrm{P}<$ 0.01 and $\mathrm{P}<0.05)$. For common mugwort, year significantly influenced the number of stems per plant, stem height, dry mass productivity $(\mathrm{p}<0.01)$ and fresh mass $(\mathrm{p}<0.05)$. In a similar way, nitrogen rate positively influenced all four yield parameters and nitrogen use efficiency (NUE) $(\mathrm{p}<0.01)$. However, the interaction of both parameters $(\mathrm{Y} \times \mathrm{N})$ 
had a positive impact on the number of stems per plant and NUE $(\mathrm{p}<0.01)$. Although liming had no significant effect on yield parameters, liming rate (or growing under different soil $\mathrm{pH}$ levels) had a significant impact on NUE $(\mathrm{p}<0.01)$. Lime use efficiency (LUE) was not influenced by any of these three factors or their interactions.

Year as a factor had a significant impact on all parameters of cup plant $(p<0.01)$. Nitrogen rate positively influenced the number of stems per plant, fresh and dry mass $(\mathrm{p}<0.01)$. Although liming had no statistically significant impact on individual yield parameters, it significantly influenced fresh mass $(\mathrm{p}<0.05)$ and dry mass $(\mathrm{p}<0.05)$ yield.

The impact of nitrogen rate and liming rate $(\mathrm{L} \times \mathrm{N})(\mathrm{p}<0.05)$ on stem height of cup plant was only statistically positive mutual interaction for cup plant.

Table 1. Fisher criterion's mean squares for common mugwort, cup plant and Virginia mallow yield parameters, lime and nitrogen efficiency (LUE, NUE)

\begin{tabular}{|c|c|c|c|c|c|c|}
\hline Variable & $\begin{array}{c}\text { Number of } \\
\text { stems plant }^{-1}\end{array}$ & $\begin{array}{l}\text { Stem } \\
\text { height } \\
(\mathrm{cm})\end{array}$ & $\begin{array}{c}\text { Fresh } \\
\text { mass } \\
\left(\mathrm{t} \mathrm{ha}^{-1}\right)\end{array}$ & $\begin{array}{c}\text { Dry } \\
\text { mass } \\
\left(\mathrm{t} \mathrm{ha}^{-1}\right)\end{array}$ & $\begin{array}{c}\mathrm{NUE} \\
\left(\mathrm{kg} \mathrm{kg}^{-1}\right)\end{array}$ & $\begin{array}{c}\text { LUE } \\
\left(\mathrm{kg} \mathrm{t}^{-1}\right)\end{array}$ \\
\hline \multicolumn{7}{|c|}{ Common mugwort } \\
\hline Year & $29.63 * *$ & $10.32 * *$ & $2.98 *$ & $4.11 * *$ & $23.50 * *$ & 0.51 \\
\hline Liming rate & 1.87 & 0.01 & 0.44 & 0.99 & $5.57 * *$ & 1.34 \\
\hline Nitrogen rate & $4.52 * *$ & $24.98 * *$ & $25.00 * *$ & $16.26 * *$ & 0.02 & 0.12 \\
\hline Y x L & $6.34 * *$ & 0.57 & 0.64 & 0.65 & $4.91 * *$ & 0.47 \\
\hline $\mathrm{Y} \times \mathrm{N}$ & 2.13 & 0.99 & 0.69 & 0.57 & 0.65 & 0.91 \\
\hline $\mathrm{L} \times \mathrm{N}$ & 1.42 & 0.81 & 0.62 & 0.10 & 2.01 & 0.23 \\
\hline $\mathrm{Y} \times \mathrm{L} \times \mathrm{N}$ & 0.57 & 1.63 & 0.51 & 0.43 & 2.12 & 0.37 \\
\hline \multicolumn{7}{|c|}{ Cup plant } \\
\hline Year & $152.05 * *$ & $138.24 * *$ & $49.88 * *$ & $55.90 * *$ & $5.62 * *$ & $6.32 * *$ \\
\hline Liming rate & 2.02 & 0.19 & $4.22 *$ & $5.82 * *$ & 0.76 & 2,42 \\
\hline Nitrogen rate & $9.70 * *$ & 1.31 & $7.64 * *$ & $5.43 * *$ & 0.01 & 1,5 \\
\hline $\mathrm{Yx} \mathrm{L}$ & 0.74 & 1.35 & 1.02 & 1.50 & 1.95 & 1,62 \\
\hline $\mathrm{YxN}$ & 0.67 & 0.34 & 0.32 & 0.11 & 1.64 & 0,84 \\
\hline $\mathrm{L} \times \mathrm{N}$ & 1.03 & $2.84 *$ & 2.36 & 1.16 & 1.67 & 1,36 \\
\hline $\mathrm{Y} \times \mathrm{L} \times \mathrm{N}$ & 1.17 & 0.26 & 0.19 & 0.14 & 0.74 & 0,15 \\
\hline \multicolumn{7}{|c|}{ Virginia mallow } \\
\hline Year & $19.44 * *$ & $17.52 * *$ & $50.00 * *$ & $9.69 * *$ & $22.18 * *$ & $4.51 *$ \\
\hline Liming rate & $12.64 * *$ & $3.36 *$ & $16.73 * *$ & $15.69 * *$ & $6.11 * *$ & 0,25 \\
\hline Nitrogen rate & $22.58 * *$ & $4.27 *$ & $52.63 * *$ & $48.71 * *$ & 1.46 & $28.01 * *$ \\
\hline Y x L & 0.46 & 0.42 & 1.19 & 1.40 & $19.7 * *$ & 2,39 \\
\hline $\mathrm{Y} \times \mathrm{N}$ & 1.05 & 0.55 & $6.19 * *$ & $3.69 *$ & 0.91 & 1,12 \\
\hline $\mathrm{L} \times \mathrm{N}$ & 0.30 & 0.11 & 2.14 & 2.02 & $17.62 * *$ & 1,79 \\
\hline$Y \times L \times N$ & 0.62 & 0.43 & 1.58 & 1.10 & $5.04 * *$ & 0,39 \\
\hline
\end{tabular}

$*, * *$ - significant at $\mathrm{P}<0.05$ and $\mathrm{P}<0.01$ levels, respectively

As for Virginia mallow, all three investigated factors had a positive impact to all studied parameters $(\mathrm{p}<0.05$ or $\mathrm{P}<0.01)$. However, both liming and nitrogen use efficiency $\left(\mathrm{kg} \mathrm{kg}^{-1}\right.$ ) (or LUE and NUE) were not significantly affected by liming and nitrogen rates, respectively. In some cases, the interactions between the factors were 
statistically significant. Thus, nitrogen use efficiency was significantly affected by $\mathrm{Y} x$ $\mathrm{L}, \mathrm{L} \times \mathrm{N}$ and $\mathrm{Y} \times \mathrm{L} \times \mathrm{N}$ interactions $(\mathrm{P}<0.01)$. The interaction $\mathrm{Y} \times \mathrm{N}$ positively influenced fresh $(\mathrm{P}<0.01)$ and dry mass $(\mathrm{P}<0.05)$ of Virginia mallow. These results suggest that compared with other investigated species, Virginia mallow is more susceptible to biotic and abiotic factors.

\section{Yield and its structure}

The smallest number of mugwort stems was observed in the first harvest year (in 2009) - 8.42 stems plant $^{-1}$ (Table 1). In the next two years, the number of stems increased significantly up to 17.68 stems plant $^{-1}$ (or 4.84 times) (in 2011). This indicates that with the increasing common mugwort age, its branching ability becomes stronger. The role of liming was less visible. On average, the application of $120 \mathrm{~kg} \mathrm{ha}^{-1} \mathrm{~N}$ increased the number of mugwort stems up to 15.65 plant $^{-1}$.

Depending on the growing year, the average stem height varied from 82.47 to 90.73 $\mathrm{cm}$. Although statistically significant, the effect of year on stem height was less noticeable than for other parameters. There was no significant effect of liming on stem height. There was a significant effect of $120 \mathrm{~kg} \mathrm{ha}^{-1} \mathrm{~N}$ application - the average stem height increased up to $94.70 \mathrm{~cm}$.

The highest common mugwort biomass productivity (both, FM and DM yield) was recorded in 2009. In this year, the average FM and DM yield was 6.93 and $4.10 \mathrm{t} \mathrm{ha}^{-1}$, respectively. Herewith, the productivity significantly decreased in the following two years. It is probable that the decrease of common mugwort yield was determined by droughty periods in 2010 and 2011 seasons at the intensive growth stage of aboveground biomass, when significant parts of already synthesized DM are exhausted during the intense respiration. Besides, common mugwort might be more sensitive to water deficit in the upper soil layer due to a shallow root system. Statistical analysis showed that the application of $6.0 \mathrm{t} \mathrm{ha}^{-1} \mathrm{CaCO}_{3}$ rate significantly increased $\mathrm{DM}$ yield; however, the positive effect of liming was observed just in individual cases. The minor effect of liming material on mugwort productivity could be explained by the fact that the species is undemanding in terms of soils and soil pH levels (Barney and DiTomasso 2003). In all the treatments, the application of $\mathrm{N}$ fertilizers substantially increased mugwort $\mathrm{FM}$ as well as DM yield.

The correlation-regression analysis revealed that both the number of stems per plant and stem height strongly correlated with common mugwort FM and DM yield.

On the other hand, the relatively low common mugwort biomass productivity could be increased by increasing plant density per unit area. According to the results of other investigations conducted in Central Lithuania's Arenosols, by application of $120 \mathrm{~kg} \mathrm{ha}^{-1}$ $\mathrm{N}$ rate and plant density of 40 thousand $\mathrm{ha}^{-1}$ (twice more than in our experiment), the average common mugwort DM yield in the second growing season was $9.38 \mathrm{t} \mathrm{ha}^{-1}$ (Kryževičienė et al., 2010).

The lowest number of cup plant stems was observed in the first harvest year (in 2009) - 5.68 stems plant $^{-1}$ (Table 2). In the subsequent two growing seasons, the number of stems significantly increased up to 12.18 stems plant $^{-1}$ (in 2011) (or 214\% higher compared with 2009 season's results). Liming material had no statistically significant impact on the number of stems. However, the presented data revealed that there was a trend that nitrogen application significantly increased the number of stems. It is estimated by other experiments that depending on cup plant age, the number of stems per plant varied from 10 to 25 (Wrobel et al., 2013). 
Table 2. The influence of liming and nitrogen rates on the mean values of common mugwort yield and yield components in $2009-2012$

\begin{tabular}{|c|c|c|c|c|}
\hline Variable & $\begin{array}{r}\text { Number of } \\
\text { stems plant }\end{array}$ & $\begin{array}{l}\text { Stem height } \\
(\mathrm{cm})\end{array}$ & $\begin{array}{c}\text { Fresh mass } \\
\left(\mathrm{t} \mathrm{ha}^{-1}\right)\end{array}$ & $\begin{array}{c}\text { Dry mass } \\
\left(\mathrm{t} \mathrm{ha}^{-1}\right)\end{array}$ \\
\hline Cultivation year (Y) & \multicolumn{4}{|c|}{ Means } \\
\hline 2009 & 8.42 & 88.71 & 6.93 & 4.10 \\
\hline 2010 & 15.46 & 82.47 & 5.72 & 3.29 \\
\hline 2011 & 17.68 & 90.73 & 6.12 & 3.08 \\
\hline 2012 & 14.94 & 75.40 & 6.97 & 3.58 \\
\hline$L S D(\text { for } Y)_{05 / 01}$ & $1.26 / 1.68$ & $3.72 / 4.94$ & $0.62 / 0.82$ & $0.38 / 0.50$ \\
\hline Liming rate $(\mathrm{L})$ & \multicolumn{4}{|c|}{ Means } \\
\hline Not limed & 13.23 & 84.50 & 6.42 & 3.71 \\
\hline 0.5 rate & 14.19 & 84.41 & 6.24 & 3.33 \\
\hline 1.0 rate & 14.96 & 84.08 & 6.65 & 3.50 \\
\hline Nitrogen rate $(\mathrm{N})$ & \multicolumn{4}{|c|}{ Means } \\
\hline $0 \mathrm{~kg} \mathrm{ha}^{-1}$ & 13.69 & 74.74 & 5.08 & 2.84 \\
\hline $60 \mathrm{~kg} \mathrm{ha}^{-1}$ & 13.05 & 84.89 & 6.10 & 3.37 \\
\hline $120 \mathrm{~kg} \mathrm{ha}^{-1}$ & 15.64 & 93.35 & 8.12 & 4.33 \\
\hline$L S D(\text { for } L \text { and } N)_{05 / 01}$ & $1.03 / 1.37$ & $3.04 / 4.03$ & $0.50 / 0.67$ & $0.31 / 0.41$ \\
\hline
\end{tabular}

Likewise, stems were short in the $1^{\text {st }}$ harvest year $-123 \mathrm{~cm}$, on average. The next two years, the average stem height significantly increased and varied from 175 to 179 $\mathrm{cm}$. The cultivation of cup plants under different soil $\mathrm{pH}$ (differing in liming level) had no impact on stem height. The application of $\mathrm{N}$ fertilizers had a slight, but at the same time insignificant effect on stem height.

Cup plant biomass productivity (FM and DM yield) was low in the first harvest year -19.17 and $6.74 \mathrm{t} \mathrm{ha}^{-1}$, respectively (Table 3). However, it substantially increased in the next two harvest years and reached the highest productivity in the third year of growing -45.20 of FM yield and $13.48 \mathrm{t} \mathrm{ha}^{-1}$ of DM yield, on average. These results agree with other authors' observations that the cup plant yield in the first years is usually low; however it increases substantially in the following years (Filatov et al., 1986). However, based on the data of different authors, cup plant productivity is highly varied depending on agroclimatic conditions as well as cultivation technology (Kowalski, 2004, 2007; Voigt et al., 2013; Gangsberger et al., 2015).

The correlation-regression analysis revealed that both the number of stems per plant and stem height strongly correlated with common mugwort FM and DM yield.

However, there was no strong correlation between cup plant biomass yield (both FM and DM) and both number of stems and stem height. Therefore, it can be assumed that with increasing cup plant biomass yield, the mass of individual stems also tends to increase.

For the first two growing years, the number of stems and stem height of Virginia mallow were insignificant was similar. However, biomass productivity was significantly different. In the $2^{\text {nd }}$ year of growing, the above-ground biomass reached its highest peak - $15.21 \mathrm{t} \mathrm{ha}^{-1}$ of FM and $6.24 \mathrm{t} \mathrm{ha}^{-1}$ of DM (Table 4). This suggests that in 2011, individual stems of Virginia mallow were thicker and heavier than in 2010. The highest number of stems (9.33 per plant) and the highest stem height $(233 \mathrm{~cm})$ was in 2012. However, biomass productivity was comparable to that in 2011 season.

The application of 1.0 liming rate substantially increased the productivity parameters as well as the biomass yield. A similar effect was exerted by the highest nitrogen rate $\left(120 \mathrm{~kg} \mathrm{ha}^{-1}\right)$ (at $99 \%$ probability level). 
Table 3. The influence of liming and nitrogen rates on the mean values of cup plant yield and yield components in $2009-2012$

\begin{tabular}{|c|c|c|c|c|}
\hline Variable & $\begin{array}{c}\text { Number of } \\
\text { stems plant }^{-1}\end{array}$ & $\begin{array}{l}\text { Stem height } \\
\text { (cm) }\end{array}$ & $\begin{array}{l}\text { Fresh mass } \\
\left(\mathrm{t} \mathrm{ha}^{-1}\right)\end{array}$ & $\begin{array}{c}\text { Dry mass } \\
\left(\mathrm{t} \mathrm{ha}^{-1}\right)\end{array}$ \\
\hline Cultivation year (Y) & \multicolumn{4}{|c|}{ Means } \\
\hline 2009 & 11.35 & 123 & 19.17 & 6.74 \\
\hline 2010 & 20.76 & 175 & 41.26 & 13.14 \\
\hline 2011 & 12.18 & 179 & 45.20 & 13.48 \\
\hline 2012 & 15.79 & 186 & 40.56 & 11.42 \\
\hline$L S D(\text { for } Y)_{05 / 01}$ & $0.60 / 0.80$ & $3.72 / 4.94$ & $2.81 / 3.73$ & $1.24 / 1.64$ \\
\hline Liming rate $(\mathrm{L})$ & \multicolumn{4}{|c|}{ Means } \\
\hline Not limed & 14.51 & 165 & 31.19 & 11.21 \\
\hline 0.5 rate & 15.16 & 167 & 33.99 & 12.16 \\
\hline 1.0 rate & 15.38 & 156 & 36.97 & 13.76 \\
\hline Nitrogen rate $(\mathrm{N})$ & \multicolumn{4}{|c|}{ Means } \\
\hline $0 \mathrm{~kg} \mathrm{ha}^{-1}$ & 11.35 & 163 & 30.15 & 10.99 \\
\hline $60 \mathrm{~kg} \mathrm{ha}^{-1}$ & 15.60 & 167 & 34.05 & 12.47 \\
\hline $120 \mathrm{~kg} \mathrm{ha}^{-1}$ & 15.99 & 167 & 37.94 & 13.67 \\
\hline$L S D(\text { for } L \text { and } N)_{05 / 01}$ & $0.49 / 0.65$ & $3.04 / 4.03$ & $2.29 / 3.05$ & $1.01 / 1.34$ \\
\hline
\end{tabular}

Table 4. The influence of liming and nitrogen rates on the mean values of Virginia mallow yield and yield components in $2010-2012$

\begin{tabular}{|c|c|c|c|c|}
\hline Variable & $\begin{array}{c}\text { Number of stems } \\
\text { plant }^{-1}\end{array}$ & $\begin{array}{l}\text { Stem height } \\
(\mathrm{cm})\end{array}$ & $\begin{array}{c}\text { Fresh mass } \\
\left(\mathrm{t} \mathrm{ha}^{-1}\right)\end{array}$ & $\begin{array}{c}\text { Dry mass } \\
\left(\mathrm{t} \mathrm{ha}^{-1}\right)\end{array}$ \\
\hline Cultivation year (Y) & \multicolumn{4}{|c|}{ Means } \\
\hline 2010 & 6.24 & 195 & 8.06 & 4.68 \\
\hline 2011 & 6.41 & 192 & 15.21 & 6.24 \\
\hline 2012 & 9.33 & 223 & 14.80 & 6.00 \\
\hline Liming rate $(\mathrm{L})$ & \multicolumn{4}{|c|}{ Means } \\
\hline Not limed & 6.11 & 194 & 10.34 & 4.51 \\
\hline 0.5 rate & 7.01 & 207 & 12.74 & 5.75 \\
\hline 1.0 rate & 8.86 & 209 & 14.98 & 6.65 \\
\hline Nitrogen rate $(\mathrm{N})$ & \multicolumn{4}{|c|}{ Means } \\
\hline $0 \mathrm{~kg} \mathrm{ha}^{-1}$ & 5.56 & 198 & 8.67 & 3.84 \\
\hline $60 \mathrm{~kg} \mathrm{ha}^{-1}$ & 7.12 & 200 & 12.49 & 5.48 \\
\hline $120 \mathrm{~kg} \mathrm{ha}^{-1}$ & 9.29 & 213 & 16.90 & 7.60 \\
\hline$L S D(\text { for } Y, L \text { and } N)_{05 / 01}$ & $0.65 / 0.86$ & $6.74 / 8.98$ & $0.93 / 1.24$ & $4.44 / 5.91$ \\
\hline
\end{tabular}

The data of other researchers suggest that the productivity of Virginia mallow is not high in the $1^{\text {st }}$ year of growing. It is substantially increasing in the subsequent growing years. Some authors have noted that the average annual yield per 4 years' cycle is not high $-6.85 \mathrm{t} \mathrm{ha}^{-1}$ (Borkowska et al., 2001). Other researches state that by growing mallow from seeds, the annual DM yield varies from 9 to $17 \mathrm{t} \mathrm{ha}^{-1}$; meanwhile when mallow is planted by root cuttings, DM yield reaches up to $20 \mathrm{t} \mathrm{ha}^{-1}$ (Borkowska, 2007; Borkowska and Molas, 2012).

\section{Lime use efficiency (LUE) and nitrogen use efficiency (NUE)}

As it was mentioned, the liming was performed in 2008; thus, the highest soil pH rates were measured in the second half of 2010 (these data are not presented in the article). Herewith, for both crops - cup plant and Virginia mallow, the highest LUE 
values were obtained in 2010 season -1103 and $620 \mathrm{~kg} \mathrm{t}^{-1}$, respectively (Table 5). In subsequent years, the effect of liming substantially decreased. For both crops, the liming rate had a significant and positive effect on LUE (at 99\% probability level). As well, nitrogen rate significantly increased LUE values at 95\% (for cup plant) and 99\% (for Virginia mallow) probability level. Here we did not include LUE values of mugwort, since the species is not susceptible to the impact of liming.

Table 5. LUE and NUE mean values of common mugwort, cup plant (in 2009-2012) and Virginia mallow (in 2010 - 2012)

\begin{tabular}{|c|c|c|c|c|c|}
\hline \multirow[b]{2}{*}{ Variable } & \multicolumn{2}{|c|}{$\operatorname{LUE}\left(\mathrm{kg} \mathrm{t}^{-1}\right)$} & \multicolumn{3}{|c|}{$\operatorname{NUE}\left(\mathrm{kg} \mathrm{kg}^{-1}\right)$} \\
\hline & Cup plant & $\begin{array}{l}\text { Virginia } \\
\text { mallow }\end{array}$ & $\begin{array}{l}\text { Common } \\
\text { mugwort }\end{array}$ & Cup plant & $\begin{array}{l}\text { Virginia } \\
\text { mallow }\end{array}$ \\
\hline Cultivation year & \multicolumn{5}{|c|}{ Means } \\
\hline 2009 & 208 & - & 30.71 & 30.40 & - \\
\hline 2010 & 1103 & 620 & 10.50 & 59.69 & 33.42 \\
\hline 2011 & 480 & 251 & 11.14 & 53.07 & 46.17 \\
\hline 2012 & 159 & 281 & 15.18 & 23.55 & 25.07 \\
\hline$L S D_{05 / 01}$ & $301 / 402$ & $160 / 215$ & $3.40 / 4.53$ & $12.82 / 17.12$ & $3.74 / 5.03$ \\
\hline Liming rate & \multicolumn{5}{|c|}{ Means } \\
\hline Not limed & - & - & 21.48 & 44.14 & 21.48 \\
\hline 0.5 rate & 353 & 356 & 14.77 & 45.58 & 14.77 \\
\hline 1.0 rate & 622 & 412 & 14.41 & 35.31 & 14.41 \\
\hline$L S D_{05 / 01}$ & $174 / 232$ & $113 / 152$ & $2.77 / 3.70$ & $10.47 / 13.98$ & $3.74 / 5.03$ \\
\hline Nitrogen rate & \multicolumn{5}{|c|}{ Means } \\
\hline $0 \mathrm{~kg} \mathrm{ha}^{-1}$ & 321 & -48 & - & - & - \\
\hline $60 \mathrm{~kg} \mathrm{ha}^{-1}$ & 459 & 251 & 17.03 & 42.02 & 17.03 \\
\hline $120 \mathrm{~kg} \mathrm{ha}^{-1}$ & 683 & 949 & 16.75 & 41.33 & 16.75 \\
\hline$L S D_{05 / 01}$ & $246 / 328$ & $160 / 215$ & $1.96 / 2.62$ & $7.40 / 9.88$ & $2.65 / 3.55$ \\
\hline
\end{tabular}

Liming (or increasing soil $\mathrm{pH}$ ) increases calcium $(\mathrm{Ca})$ availability in plant rooting zone (rhizosphere), which, in turn, enhances the ability of plants to accumulate higher amounts of individual nutrients (including nitrogen $(\mathrm{N})$ ) and benefit high above ground biomass yields (Bailey, 1995; Hallbacken and Zhang, 1998, Karcauskiene and Repsiene, 2009).

The highest nitrogen use efficiency (NUE) values were obtained in the $1^{\text {st }}$ (for common mugwort) and $2^{\text {nd }}$ years of growing (for cup plant and virginia mallow) (Table 4). In the subsequent years, the efficiency of $\mathrm{N}$ fertilizers declined substantially. Out of the three species, depending on the growing season, the highest was cup plant nitrogen use efficiency which varied from 23.55 (in 2012) to $59.69 \mathrm{~kg} \mathrm{~kg}^{-1}$ (in 2010).

It is interesting to note that the highest nitrogen use efficiency was determined in the control treatments (without liming). Although it has been proven that common mugwort could grow well under a wide range of $\mathrm{pH}$ levels and liming has a negligible effect on species DM productivity, the use of nitrogen fertilizers was substantially higher (at $99 \%$ probability level) when cultivating in non-limed treatments (where soil $\mathrm{pH}$ was 4.2-4.4). A similar effect was noted for Virginia mallow. We presume that the application of nitrogen could to some extent reduce the negative effect of high soil acidity.

The application of two different nitrogen rates $\left(60\right.$ and $\left.120 \mathrm{~kg} \mathrm{ha}^{-1}\right)$ had a similar effect on nitrogen efficiency. Thus, the application of the highest nitrogen rate $(120 \mathrm{~kg}$ $\left.\mathrm{ha}^{-1}\right)$ in two applications $\left(60+60 \mathrm{~kg} \mathrm{ha}^{-1}\right)$ was optimal for all three crops. 
These experiments produced some valuable material concerning agronomic traits and energy characteristics of the tested crops. Cup plant has already received a substantial interest as an energy crop in many countries. Our experimental results concerning high biomass yield are in agreement with the data of other authors (Kowalski, 2004; 2007). However, the expansion of cup plant is restricted by some factors. So far, another coarse stemmed crop - maize (Zea mays L.) has been much more frequently used for biogas production than cup plant. Besides, in the first year of growing, cup plant lacks harvestable biomass. Altogether, it is necessary to elaborate weed control technology in the first year of growing (Gangsberger et al., 2015).

Our experimental data corroborated what has also been established by other authors that Virginia mallow biomass could potentially be used for liquid and solid fuel production. As well, it is necessary to elaborate and improve agro-technical methods, since Virginia mallow has never been cultivated in large-area plantations (Borkowska, and Molas, 2012).

Concerning the common mugwort, the sparse experimental data indicate that mugwort biomass has good quality parameters and is suitable for solid biofuel production (Kryževičienè et al., 2010; Jasinskas et al., 2014). As it has already been mentioned, the species has a high tolerance of different soil conditions; however, in our trials mugwort biomass productivity and biomass potential were found to be low.

Currently, the investigation on these species is being continued with a primary focus on the energy parameters of biomass and its suitability for a specific biofuel type.

Aknowledgements. The study was conducted in compliance with the long term program "Plant biopotential and quality multifunctional practice".

\section{REFERENCES}

[1] Bailey, J. S. (1995): Liming and nitrogen efficiency: some effects of increased calcium supply and increased soil $\mathrm{pH}$ on nitrogen recovery by perennial ryegrass. Communication of Soil Science and Plant Analysis 26(7-8): 1233-1246.

[2] Barney, J.N., DiTommaso, A. (2003): The biology of Canadian weeds. 118. Artemisia vulgaris L. - Canadian Journal of Plant Science 83: 203-215.

[3] Borkowska, H. (2007): Yield of Virginia fanpetals and willow on good wheat soil complex. - Fragmenta Agronomica 2: 81-99.

[4] Borkowska, H., Molas, R. (2012): Two extremely different crops, Salix and Sida, as sources of renewable bioenergy. - Biomass and bioenergy 36: 234-240.

[5] Borkowska, H., Molas, R. (2013): Yield comparison of four lignocellulosic perennial energy crop species. - Biomass and Bioenergy 51: 145-153.

[6] Clevinger, J.A., Panero, J.L. (2000): Phylogenetic analysis of Silphium and subtribe Engelmanninae (Asteraceae: Heliantheae) based on ITS and ETS sequence data. American Journal of Botany 87: 565-572.

[7] Filatov, V.I., Bakalov, A.M., Lavrov, B.V., Komyagin, N.A. (1986): Productivity of Silhium perfoliatum as a function of agricultural technology practices on ameliorated soils. - Biological Abstracts 82: 58-63.

[8] Franzaring J., Schmid I., Bauerle L., Gensheimer G., Fangmeier, A. (2014): Investigations on plant functional traits, epidermal structures and the ecophysiology of the novel bioenergy species Sida hermaphrodita Rusby and Silphium perfoliatum L. Journal of Applied Botany and Food Quality 87: 36-45. 
[9] Gan, Y., Malhi, S. S., Brandt, S., Katepa-Mupondwa, F., Stevenson, C. (2008): Nitrogen use efficiency and nitrogen uptake of juncea canola under diverse environments. Agronomy Journal 100: 285-295.

[10] Gansberger, M., Montgomery, L.F.R., Liebhard, P. (2015): Botanical characteristics, crop management and potential of Silphium perfoliatum L. as a renewable resource for biogas production: A review - Industrial Crops and Products 63: 362-372.

[11] Hallbäcken, L., Zhang, L. Q. (1998): Effects of experimental acidification, nitrogen addition and liming on ground vegetation in a mature stand of Norway spruce (Picea abies (L.) Karst.) in SE Sweden. - Forest Ecology and Management 108(3): 201-213.

[12] Huxley, A. (1992): The New RHS Dictionary of Gardening - MacMillan Press, London

[13] Jasinskas, A., Simonavičiūtė, R., Šiaudinis, G., Liaudanskienè, I., Antanaitis, Š., Arak, M., Olt, J. (2014): The assessment of common mugwort (Artemisia vulgaris L.) and cup plant (Silphium perfoliatum L.) productivity and technological preparation for solid biofuel - Žemdirbystè (Agriculture) 101: 19-26.

[14] Judžentienè, A., Buzelytė, J. (2006): Chemical composition of essential oils of Artemisia vulgaris L.(mugwort) from North Lithuania - Chemija 17 (1): 12-15 (in Lithuanian).

[15] Karcauskiene, D., Repsiene, R. (2009): Long-term manuring and liming effect on moraine loam soil fertility. - Agronomy research. 7 (Spec. iss. 1): 300-304.

[16] Kowalski, R. (2004): Growth and development of Silphium integrifolium in the first 3 years of cultivation. - New Zealand Journal of Crop and Horticultural Science 32: 389395

[17] Kowalski, R. (2007): Silphium trifoliatum L.- a new alternative cultivation herbal plant? - Acta Agriculturae Scandinavica Section B-Soil and Plant Science 57.2: 155-166.

[18] Kryževičienè, A., Šarūnaitè, L., Stukonis, V., Dabkevičius, Z., Kadžiulienė, Z. (2010): Assessment of perennial mugwort (Artemisia vulgaris L. and Artemisia dubia Wall.) potential for biofuel production - Žemès Ūkio Mokslai 17: 32-40 (in Lithuanian)

[19] Kujawski, J., Woolston, D., Englert, J. (1997): Propagation of Virginia mallow (Sida hermaphrodita (L.) Rusby) from seeds, rhizomes. - Restoration and Management Notes, 15: 193-194.

[20] Mažvila, J., Adomaitis, T., Eitmanavičius, L. (2004): Changes in the acidity of Lithuania's soils as affected of not liming. - Žemdirbystè (Agriculture) 88: 3-20 (in Lithuanian)

[21] McKendry, P. (2002): Energy production from biomass (part 1): overview of biomass Bioresource Technology 83: 37-46.

[22] Van Epps, G. A., Barker, J. R., McKell, C. M. (1982): Energy biomass from large rangeland shrubs of the Intermountain United States. - Journal of Range Management 35: 22-25.

[23] Voigt, T.B., Lee, D.K., Klig, G.J. (2013): Perennial herbaceous crops with potential for biofuel production in the temperate regions of the USA. - CAB Reviews 7: 1-13.

[24] Wrobel, M., Fraczek, J., Francik, S., Slipek, Z., Krzysztof, M. (2013): Influence of degree of fragmentation on chosen quality parameters of briquette made from biomass of cup plant Silphium perfoliatum L. - Conference Engineering for Rural Development, Jelgava, Latvia, 653-657. 